\title{
EHMTI-0018. CGRP receptor antagonists attenuate pain behavior induced by cortical spreading depression in freely moving rats
}

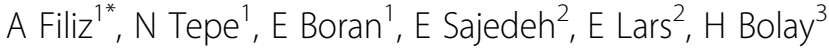 \\ From 4th European Headache and Migraine Trust International Congress: EHMTIC 2014 \\ Copenhagen, Denmark. 18-21 September 2014
}

\section{Introduction}

Cortical spreading depression (CSD) is implicated in migraine. Pain behavior is important for experimental migraine studies.

\begin{abstract}
Aims
In this study, the effect of CSD on pain and anxiety behavior in freely moving rats was investigated. The effect of CGRP receptor antagonist (MK-8825) on CSD induced behavior, and c-fos activation pattern in certain brain structures were evaluated to understand pain mechanisms.
\end{abstract}

\section{Methods}

Study was approved the Institutional Animal Care and Use Committee and care and handling of animals were in accord with National Institute of Health guidelines. CSD was performed by topical $\mathrm{KCl}$ in awake rat; basal pain thresholds to mechanical and cold allodynia were evaluated. Rats were given either saline or CGRP receptor antagonist 30 or $100 \mathrm{mg} / \mathrm{kg}$. After CSD induction, spontaneous behavior, ultrasonic vocalization was recorded; anxiety tested by elevated plus maze and mechanical and cold allodynia were evaluated. C-fos immunohistochemistry was performed to brain sections.

\section{Results}

MK-8825 reversed CSD induced freezing, grooming, head shake and wet dog shake behavior; increased mechanical and cold allodynia thresholds. MK- 8825 reduced c-fos positive cell number in ipsilateral trigeminal nucleus caudalis (TNC) and thalamic reticular

${ }^{1}$ Neurology Department, Gazi University School of Medicine, Ankara, Turkey Full list of author information is available at the end of the article nucleus. We found no co-localization with c-Fos and CGRP, CLR or RAMP1.

\section{Conclusions}

CGRP receptor antagonists dose dependently attenuated CSD induced pain response. Besides blocking central transmission at TNC, CGRP receptor antagonists may also exert their effect on thalamic reticular nucleus.

No conflict of interest.

\section{Authors' details \\ ${ }^{1}$ Neurology Department, Gazi University School of Medicine, Ankara, Turkey. ${ }^{2}$ Neurology Department, Lund University, Lund, Sweden. ${ }^{3}$ Neurology Department Neuropsychiatry Center, Gazi University School of Medicine, Ankara, Turkey.}

Published: 18 September 2014

doi:10.1186/1129-2377-15-S1-F6

Cite this article as: Filiz et al:: EHMTI-0018. CGRP receptor antagonists attenuate pain behavior induced by cortical spreading depression in freely moving rats. The Journal of Headache and Pain 2014 15(Suppl 1):F6.

Submit your manuscript to a SpringerOpen ${ }^{\circ}$ journal and benefit from:

- Convenient online submission

- Rigorous peer review

- Immediate publication on acceptance

- Open access: articles freely available online

- High visibility within the field

- Retaining the copyright to your article

Submit your next manuscript at $>$ springeropen.com (c) 2014 Filiz et al; licensee Springer. This is an Open Access article distributed under the terms of the Creative Commons Attribution License (http://creativecommons.org/licenses/by/2.0), which permits unrestricted use, distribution, and reproduction in any medium, provided the original work is properly cited. 